Journal of Current and Advance Medical Research

January 2018, Vol. 5, No. 1, pp. 23-28

http://www.banglajol.info/index.php/JCAMR

ISSN (Print) 2313-447X

ISSN (Online) 2413-323X

DOI: http://dx.doi.org/10.3329/jcamr.v5i1.36542

ORIGINAL ARTICLE

OPEN $\bigcirc$ ACCESS

\title{
Study of Bone Tumors in a Tertiary Care Hospital of Dhaka City
}

\author{
Kazi Nishat Ara Begum ${ }^{1}$, Syed Salahuddin Ahmed ${ }^{2}$, Md. Ayub Ali ${ }^{3}$ Md. Abdul Gani Mollah", \\ Md. Nurul Amin ${ }^{5}$, Subrata Ray ${ }^{6}$
}

\begin{abstract}
${ }^{1}$ Associate Professor, Department of Pathology, Shaheed Suhrawardy Medical College, Dhaka, Bangladesh; ${ }^{2}$ Associate Professor and Head, Department of Pathology, National Institute of Traumatology and Orthopedic Rehabilitation (NITOR), Dhaka, Bangladesh; ${ }^{3}$ Professor \& Head, Department of Plastic Surgery, NITOR, Dhaka, Bangladesh; ${ }^{4}$ Professor \& Head, Department of Orthopedic surgery, NITOR, Dhaka, Bangladesh; ${ }^{5}$ Assistant Professor, Department of Community Medicine, Rajshahi Medical College, Rajshahi, Bangladesh; ${ }^{6}$ Lecturer, Department of Pathology, Dhaka Medical College, Dhaka, Bangladesh
\end{abstract}

[Reviewed: 30 October 2017; Accepted on: 1 December 2017; Published on: 1 January 2018]

\section{Abstract}

Background: The wide spectrum of bone tumors, their rarity, diverse origin and tendency to produce overlapping anatomic patterns pose a definite diagnostic challenge to the orthopedic surgeons and the pathologists. Objective: The present study was intended to find the pattern of bone tumors and their anatomical locations, and histopathological characteristics in a tertiary care hospital of Dhaka. Methodology: A retrospective review of the histopathological records of patients with established diagnosis of bone tumors at National Institute of Traumatology and Orthopedic Rehabilitation (NITOR), Dhaka, Bangladesh was done from January 2015 to December 2016 for a period of two (02) years. The demographic data such as the age and sex, anatomical location and histopathological findings were studied from the existing records of the patients and their slides were reexamined. Bone lesions of inflammatory origin were excluded from this study leaving the lesions of both neoplastic and tumor-like origin for further study. Result: A total 283 cases of bone lesions were primarily included in the study. Bone lesions of inflammatory origin $(n=65)$ were excluded from this study leaving 218 lesions of both neoplastic and tumor-like origin for further study. The median age of the patients was 22 (range: $3-75$ ) years. In terms of anatomical site of the tumors, over one-third (36.6\%) was located in femur $21.1 \%$ in tibia, $12.2 \%$ in humerus, $6.1 \%$ in radius and $5.6 \%$ in ulna. In terms of types of bone tumor, 105(48.2\%) were benign, 66(30.3\%) malignant, $47(21.5 \%)$ tumor-like lesions. About $65 \%$ of the benign tumors were of Giant cell tumor, $28.5 \%$ were osteochondroma, $1 \%$ osteoma and $5.7 \%$ were of other types. Of the malignant tumors, one-third (33.3\%) was of metastatic type, 27.3\% Ewing's sarcoma, 22.7\% osteosarcoma, 9.1\% chondrosarcoma and $4.6 \%$ were of other varieties. Conclusion: Primary bone tumors are mainly benign; however, giant cell and metastatic tumors are the most common benign and malignant bone tumors respectively. [Journal of Current and Advance Medical Research 2018;5(1):23-28]

Keywords: Bone tumors; benign; malignant; tumor-like lesions

Correspondence: Dr. Kazi Nishat Ara Begum, Associate Professor, Department of Pathology, Shaheed Suhrawardy Medical College, Sher-E-Bangla Nagar, Dhaka, Bangladesh; Email: knab63@gmail.com; Cell no.: +8801795362641

Cite this article as: Begum KNA, Ahmed SS, Ali MA, Mollah MAG, Amin MN, Ray S. Study of Bone Tumors in a Tertiary Care Hospital of Dhaka City. J Curr Adv Med Res 2018;5(1):23-28

Conflict of Interest: All the authors have declared that there was no conflict of interest.

Contributions to authors: Begum KNA, Ahmed SS \& Mollah MAG have contributed in protocol preparation upto surgical procedures \& the report writing; furthermore; Begum KNA, Ali MA, Ray S have written \& revised the manuscript. Begum KNA \& Amin MN have contributed in statistical analysis and interpretation of data.

Copyright: (2018 Begum et al. Published by Journal of Current and Advance Medical Research. This article is published under the Creative Commons CC BY-NC License (https://creativecommons.org/licenses/by-nc/4.0/). This license permits use, distribution and reproduction in any medium, provided the original work is properly cited, and is not used for commercial purposes. 


\section{Introduction}

Bone tumors are infrequently encountered diseases constituting only $0.5 \%$ of the total world cancer incidence compared to the occurrence of other neoplastic lesions ${ }^{1}$. However, they are of great significance because majority of them affect adolescents and young adults with a tendency of aggressive course ${ }^{2}$.Besides, the wide spectrum of these tumors, their diverse origin from the multiple cell types found in bones coupled with their tendency to produce overlapping anatomic patterns make them a complicated but highly challenging area from the point of view of morphological diagnosis ${ }^{3}$.

Primary bone cancer is much rarer than bone metastasis. Bone is the third most common site of metastatic disease. As far as secondary tumors are concerned primary sites like lung, kidney, thyroid, breast, gastrointestinal and melanomas produce mainly lytic lesion while others elicit mixed lytic and sclerotic reaction.

Carcinomas are much more likely to metastasize to bone than sarcomas ${ }^{4,5}$. The wide spectrum of bone tumors, their diverse origin and tendency to produce overlapping anatomic patterns present a daunting challenge to the orthopedic surgeons and the pathologists.

The challenge is heightened in developing countries due to limited diagnostic and therapeutic facilities as well as due to ignorance. The published literature on the subject is sparse in our context. As already mentioned, bone cancer is not a common malignant disease, and perhaps for this reason its etiology is not very clear. Furthermore, very few studies have been conducted in this field. Among different types of primary bone cancer, osteosarcoma constitutes the highest proportion (36\%) of cases, followed by chondrosarcoma, osteoclastoma and Ewing's sarcoma ${ }^{6}$.

The clinicians and the pathologists handling management responsibility, therefore, must have high index of suspicion as to the nature of bone lesion in order to establish the diagnosis of bone tumors.

The purpose of the present study is to determine the pattern of bone tumors including their relative frequencies, age and sex distributions, anatomical locations, and histopathological characteristics as seen in a tertiary care hospital of Dhaka.

\section{Methodology}

This retrospective review of the histopathological records of patients with established diagnosis of bone tumors at National Institute of Traumatology and Orthopedic Rehabilitation (NITOR), Dhaka, Bangladesh was done covering the period from January 2015 to December 2016 for a period of two (02) years. The demographic data such as the age and sex, anatomical site and histopathological findings were extracted from the existing records of the patients and their hematoxylin and eosin $(\mathrm{H}$ and E)-stained slides were all reexamined. Chronic inflammatory lesions of bone were excluded from this study leaving 218 lesions of neoplastic and tumor-like origin for further study. Among the bone lesions, some were primary bone tumors, some were metastatic tumors and some were tumor-like lesions. The classification was based on the current World Health Organization (WHO) histological classification of bone tumors ${ }^{7}$. Data were analyzed using SPSS (Statistical Package for Social Sciences), version 17.0 with test statistics being used were frequency distribution with corresponding percentages and median with standard deviation and range.

\section{Result}

A total 283 cases of bone lesions were primarily included in the study. Bone lesions of inflammatory origin $(n=65)$ were excluded from this study leaving 218 lesions of both neoplastic and tumorlike origin for further study.

Table 1: Distribution of Patients by Their Demographic Characteristics $(n=218)$

\begin{tabular}{|l|c|c|}
\hline $\begin{array}{l}\text { Demographic Profiles } \\
\text { Age* (yrs) }\end{array}$ & Frequency & Percentage \\
\hline$<10$ Years & 16 & 7.3 \\
\hline 10 to 20 Years & 78 & 35.8 \\
\hline 20 to 30 Years & 62 & 28.4 \\
\hline 30 to 40 Years & 23 & 10.6 \\
\hline$\geq 40$ Years & 39 & 17.9 \\
\hline Sex & & \\
\hline Male & 121 & 55.5 \\
\hline Female & 97 & 44.5 \\
\hline
\end{tabular}

$*$ Mean \pm SD age $=22.0 \pm 15.1$ years; range $=3$ to 75 years

Of the 283 patients of bone lesions primarily included in the study, 218(77.1\%) were of bone lesions as evidenced by histopathological report and $65(22.9 \%)$ were inflammatory lesions. Of the 218 patients of bone tumors and tumor-like lesions, over one-third $(35.8 \%)$ was 10 to 20 years old, $28.4 \%$ $20-30$ years, $17.9 \% 40$ or $>40$ years, $10.6 \% 30$ to 
40 years and only $7.3 \%<10$ years old. The median age of the patients was 22 years with youngest and the oldest patients being 3 and 75 years old respectively. Males outnumbered females with male to female ratio being roughly 11:9 (Table 1).

In terms of anatomical site of the tumors, over onethird $(36.6 \%)$ was located in femur $21.1 \%$ in tibia, $12.2 \%$ in humerus, $6.1 \%$ in radius and $5.6 \%$ in ulna. Fibula and pelvis each comprised $3.8 \%$ of the lesions (Table 2).

Table 2: Distribution of Patients by Their Anatomical site $(\mathrm{n}=\mathbf{2 1 3})$

\begin{tabular}{|l|c|c|}
\hline $\begin{array}{l}\text { Anatomical } \\
\text { site }\end{array}$ & Frequency & Percentage \\
\hline Femur & 78 & 36.6 \\
\hline Tibia & 45 & 21.1 \\
\hline Humerus & 26 & 12.2 \\
\hline Radius & 13 & 6.1 \\
\hline Ulna & 12 & 5.6 \\
\hline Pelvis & 8 & 3.8 \\
\hline Fibula & 8 & 3.8 \\
\hline Others & 23 & 10.8 \\
\hline
\end{tabular}

Others $=$ phalanx, jaw and calcaneum

In terms of types of bone tumor, 105(48.2\%) were benign, 66(30.3\%) malignant, 47(21.5\%) tumor-like lesions (Table 3).
Table 3: Distribution of Patients by Their Types of Bone Lesion $(\mathbf{n}=\mathbf{2 1 8})$

\begin{tabular}{|l|c|c|}
\hline $\begin{array}{l}\text { Types of bone } \\
\text { tumor }\end{array}$ & Frequency & Percentage \\
\hline Benign & 105 & 48.2 \\
\hline Malignant & & \\
Primary & 44 & 20.2 \\
Secondary & 22 & 10.1 \\
\hline Tumor-like & 47 & 21.5 \\
\hline
\end{tabular}

Over $40 \%$ of the tumor-like lesions were aneurysmal bone cyst, $38.3 \%$, fibrous dysplasia, $8.5 \%$ metaphyseal fibrous defect and $12.8 \%$ were other types of tumor-like lesions (Table 4).

Table 4: Distribution of Patients by Their Types of Tumor-Like Lesion $(n=47)$

\begin{tabular}{|l|c|c|}
\hline $\begin{array}{l}\text { Types of Tumor-like } \\
\text { lesion }\end{array}$ & Frequency & Percentage \\
\hline Fibrous dysplasia & 18 & 38.3 \\
\hline $\begin{array}{l}\text { Aneurysmal bone } \\
\text { cyst }\end{array}$ & 19 & 40.4 \\
\hline $\begin{array}{l}\text { Metaphyseal fibrous } \\
\text { defect }\end{array}$ & 4 & 8.5 \\
\hline Others & 6 & 12.8 \\
\hline
\end{tabular}

Others $=$ simple bone cyst, eosinophilic granuloma

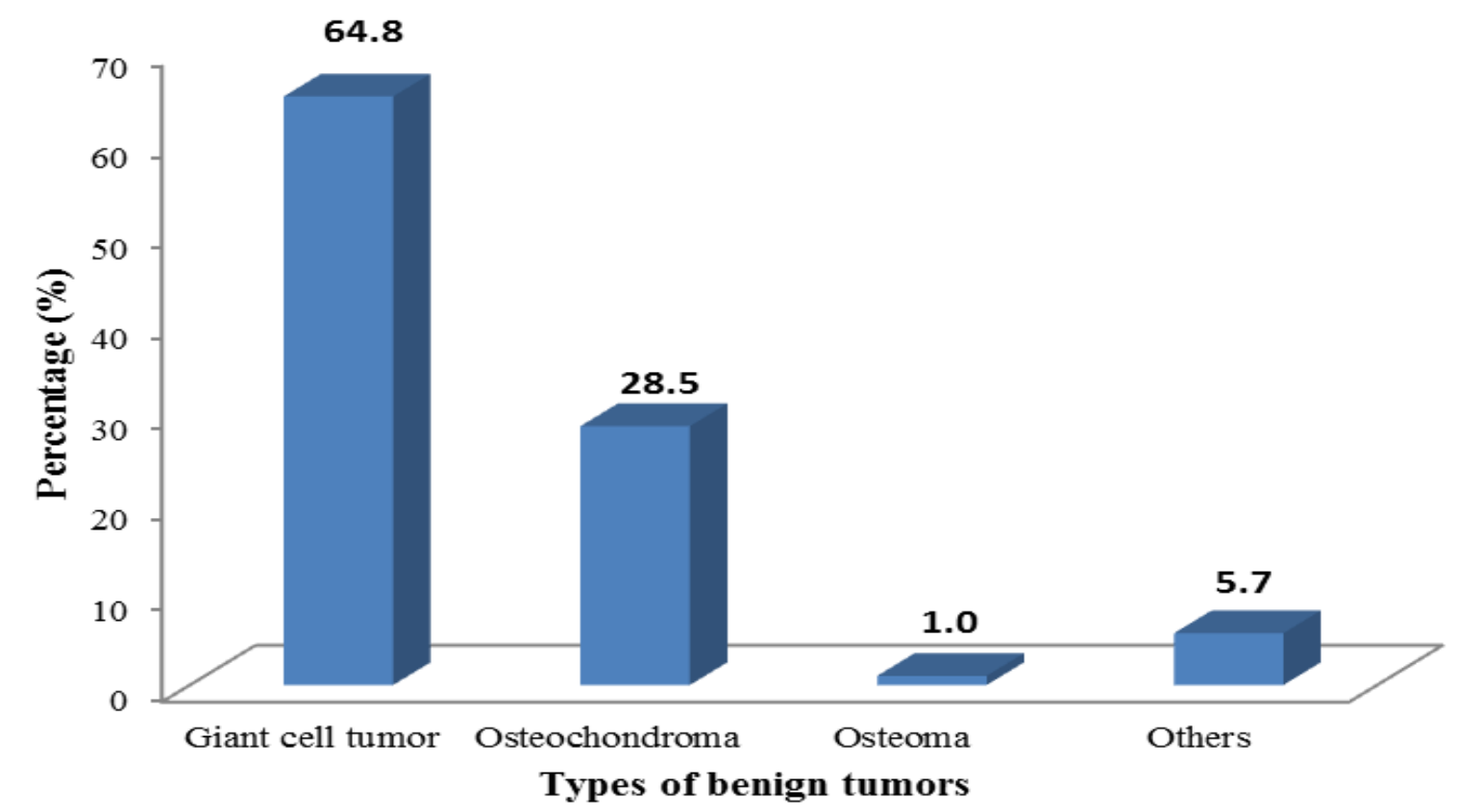

Figure I: Distribution of benign tumors by their histologic types $(n=105)$

About $65 \%$ of the benign tumors were of Giant cell tumor, $28.5 \%$ osteochondroma, $1 \%$ osteoma and
$5.7 \%$ were of other types mainly hemangioma (Figure I). 


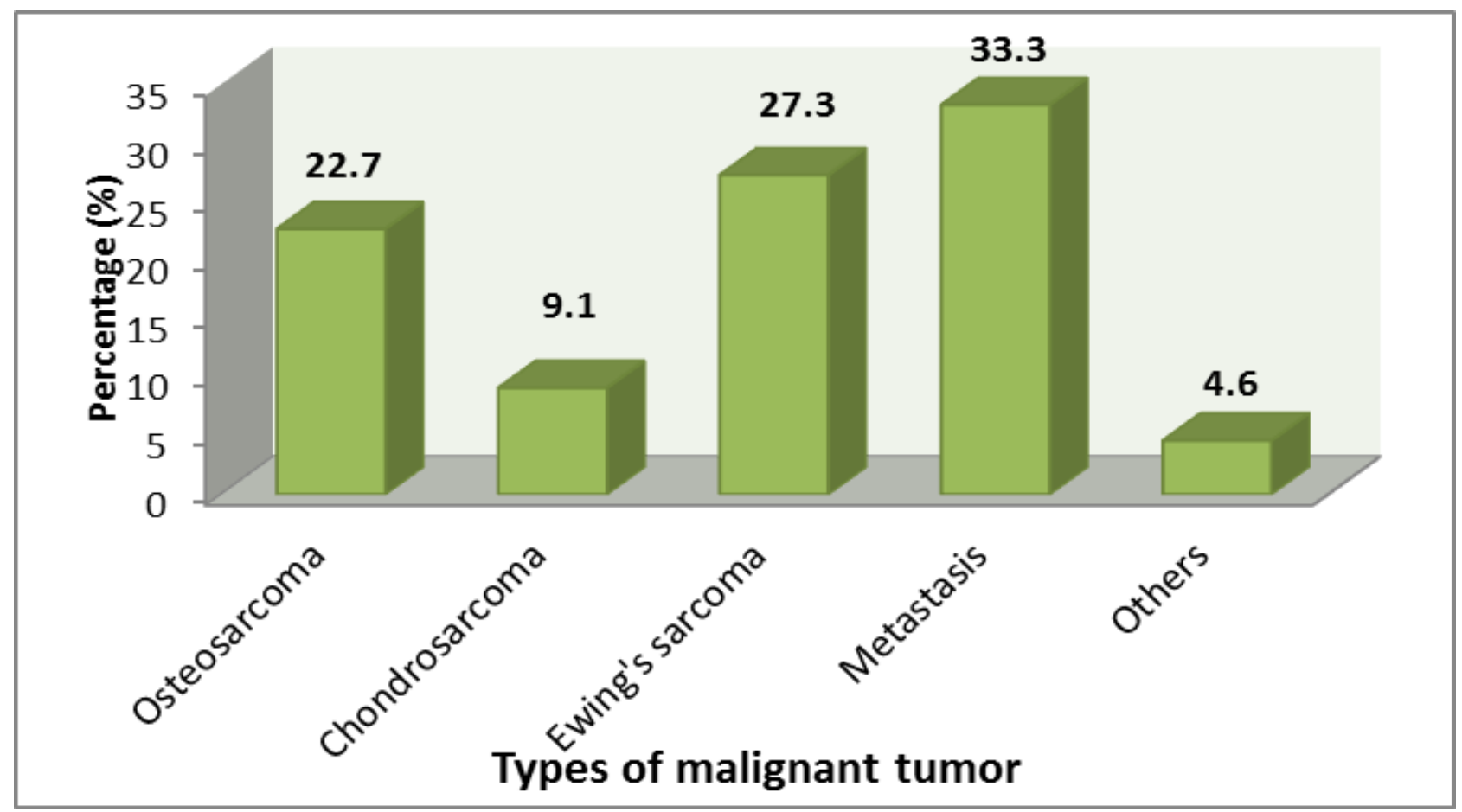

Figure II: Distribution of malignant tumors by their histologic types $(n=66)$

Of the malignant tumors, one-third (33.3\%) was metastatic type, 27.3\% Ewing's sarcoma, 22.7\% osteosarcoma, $9.1 \%$ chondrosarcoma and $4.6 \%$ were of other varieties (malignant fibrous histiocytoma, fibrosarcoma) (Figure II).

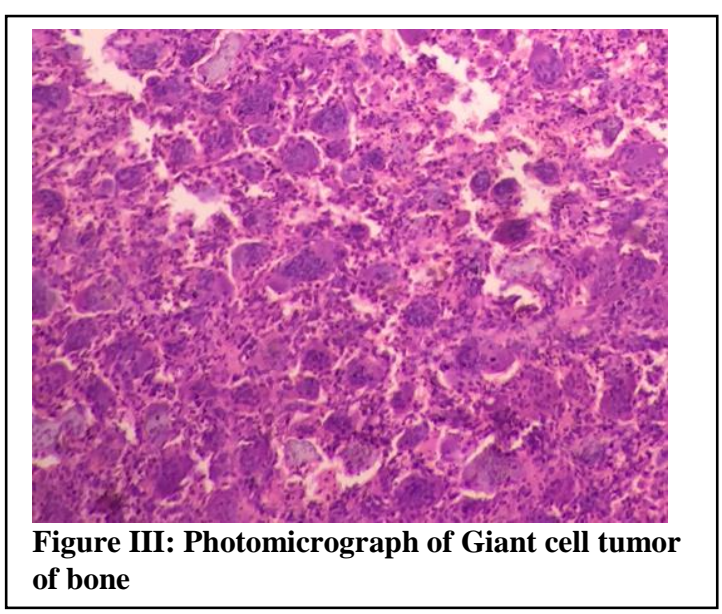

\section{Discussion}

In the present study out of 283 patients of bone lesions provisionally included in the study, $218(77 \%)$ were neoplastic bone lesions and $65(23 \%)$ were of infectious or inflammatory origin (mostly of chronic non-specific inflammation). As per enrolment criteria of the present study, the latter were excluded leaving 218 for further study. Of the neoplastic lesions, nearly half $(48.2 \%)$ was benign in nature, $30.3 \%$ malignant and $21.5 \%$ tumor-like lesions. Rhutso and colleagues ${ }^{8}$ in a study also demonstrated an almost similar distribution of neoplastic (63.3\%) and non-neoplastic lesions $(36.7 \%)$. Sharply contrasting with these findings, Modi et $\mathrm{al}^{9}$ showed that the incidence of nonneoplastic lesions was $74.5 \%$ and neoplastic lesions were $25.4 \%$. The non-neoplastic lesions were predominantly chronic osteomyelitis. A significant proportion of neoplastic bone lesions (35.8\%) in this study was seen to occur in children and adolescents (age ranging from 10 to 20 years) which compares well with the findings of Sunila et $\mathrm{al}^{6}(33.3 \%)$. Several other studies ${ }^{1,10-11}$ also reported similar findings.

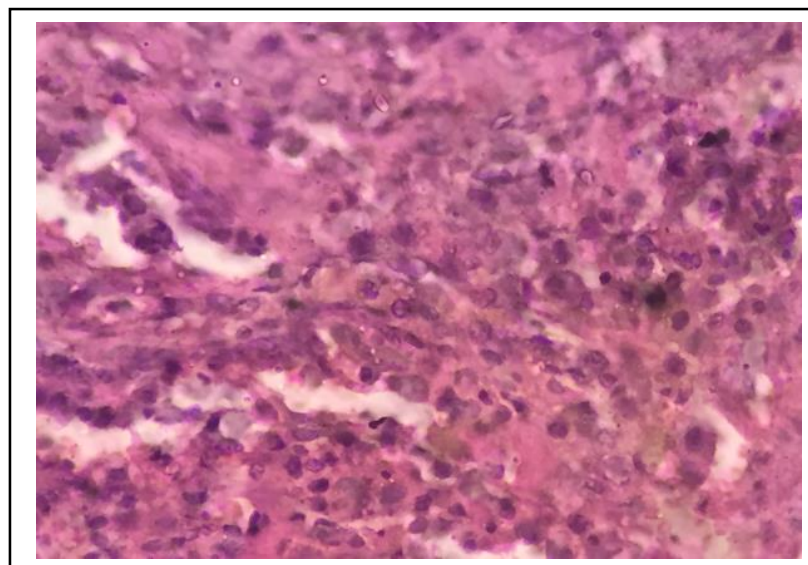

Figure IV: Photomicrograph of Osteosarcoma of bone

that long bones are the preferred site of bone tumors, for $70 \%$ of lesions were found in the three bones like femur, tibia and humerus which is 
consistent with the findings of Sunila et $\mathrm{al}^{6}$. The most common bones involved were the long bones; less commonly the jaws, vertebrae, scapula pelvis, and small bones of hands and feet were involved ${ }^{12-}$ ${ }^{15}$.Another important finding is that benign tumors were predominantly of Giant cell type, while metastatic tumors were common (33.3\%) among malignant lesions followed by Ewing's sarcoma and osteosarcoma which differs from the findings of the several other investigators $1,6,9,16$ who reported osteochondroma to be the most common benign bone tumors accounting for 20 to $40 \%$ of all the benign tumors, while osteosarcoma to be the most common primary bone tumors in young and adolescents. It occurs most frequently in the second decade, occurring in the metaphysis, mostly in lower end of femur followed by upper end of tibia ${ }^{13-}$ 15,17. Ewing sarcoma is a highly malignant, undifferentiated, peripheral primitive neuroectodermal tumor occurring most commonly at the diaphysis of long bones, in the 0 to 20 years age group, with male predominance ${ }^{13-15}$.

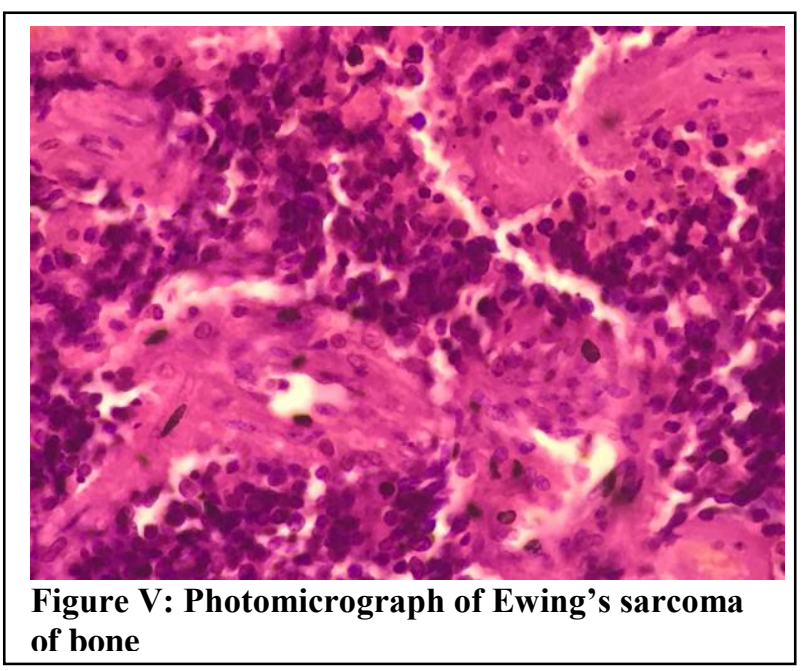

Chondrosarcoma is the most common primary malignant bone tumor in the age group of 40 to 60 years, which in our study comprised $9.0 \%$ of the malignant tumors. It commonly involves pelvis, femur, ribs, shoulder girdle, and vertebra with male predilection ${ }^{13-15}$.

Metastatic bone tumors most frequently occur in patients older than 50 years and commonly originate from lung, gastrointestinal system, prostate, breast, and liver. Femur, pelvis, vertebrae, humerus, and rib are the most common sites of metastases ${ }^{13-15,17}$. The clinical manifestation is extensive and nonspecific. Most lesions present with osteolytic patterns ${ }^{18}$. In spite of complexity, the clinical features should be mastered for early diagnosis and treatment.

\section{Conclusion}

From the findings of the study it appears that primary bone tumors are mainly benign, occur predominantly in the second decade of life with a male preponderance and predilection for long bones. Giant cell tumor and metastatic tumors are the most common benign and malignant bone tumors respectively, while Ewing's sarcoma is the common primary malignant lesions in the context of our population.

\section{References}

1. Mohammed A, Sani MA, Hezekiah IA, Enoch AA. Primary bone tumors and tumor-like lesions in children in Zaria, Nigeria. Afr J Paediatr Surg. 2010;7:16-8

2. Athanasou NA \& Woods CG. Locomotor system. In Mc Gee JD, Isacson PG \& Wright NA, editors. Oxford text book of Pathology. Oxford: Oxford university press; 1992. p. 2047-72

3. Kumavat PV, Gadgil NM, Chaudhari CS, Rathod KU, Kshirsagar RG, Margam SS. Bone Tumors and Tumorlike lesions: A study in A Tertiary Care Hospital, Mumbai. Annals of Pathology and Laboratory Medicine. 2017; 04(01):a11-a18

4. Cancer.org (internet), Atlanta, American cancer society, Detailed guide, bone metastasis. Available at: http://www.cancer.org/docroot/CRI/content/

CRI_2_4_1X_What_Is_bone_ metastasis_66.asp?sitearea=. Accessed on 24-11-2015

5. Manaster BJ. Tumors. In: Manaster BJ, Disler DG, May DA, eds. Musculoskeletal Imaging: The Requisites, 2nd edition, St. Louis, MO: Mosby; 2002, p. 1-104

6. Sunila KJ, Ravishankar R, Mruthyunjaya, Rupakumar CS, Gadiyar HB, and Manjunath GV. Bone tumors in a tertiary care hospital of south India: A review 117 cases. Indian J Med PaediatrOncol. 2011 Apr-Jun; 32(2): 82-85. doi: 10.4103/0971-5851.89778

7. Fletches CD, Unni KK, Mertens F, editors. Lyon: ARC Press; 2002. World Health Organisation Classification of Tumors. Pathology and Genetics of Tumors of Soft Tissue and Bone histological classification of bone tumors.

8. Rhutso Y, Laishram RS, Sharma LDC, Debnath KHistopathological evaluation of bone tumors in a tertiary care hospital in Manipur, India. Journal of Medical Society 2013;27(2):135-39

9. Modi D, Rathod GB, Delwadia KN, Goswami HM. Histopathological study of bone lesions - A review of 102 cases. IAIM, 2016; 3(4): 27-36

10. Gayathri T, Shashikala V, Rekha S. Spectrum of tumor and tumor-like lesions of bone in a Tertiary Care Hospital in North Karnataka, India. Indian Journal of Pathology and Oncology 2018;5(1):75-80

11. Omololu AB, Ogunbiyi JO, Ogunlade SO, Alonge TO, Adebisi A, Akang EE. Primary malignant bone tumors in Ibadan. West Afr J Med. 2002;21:201-3

12. Rai KM, Venkateswarlu S. Osteoclastoma. Indian J Radiol Imaging. 2008;18:4-11

13. Bone RJ. Ackerman's Surgical Pathology. In: Rosai J, editor. St. Louis: Mosby; 1996. pp. 1917-2020

14. Aston W, Briggs T, Solomon L. Tumors. In: Solomon L, Warwick D, Nayagam S, editors. Apley's System of Orthopaedics and Fractures. 9th ed. London: Hodder Arnold Hodder education; 2010. pp. 187-224 
15. Rosenberg AE. Bones, joints and soft tissue tumors. In: Kumar V, Abbas AK, Fausto N, Aster JC, editors. Robbins and cotran; Pathologic Basis of disease. 8th ed. Gurgaon: Elsevier Reed Elsevier India private limited; 2010. pp. 1205-56

16. Senac MO, Jr, Isaacs $\mathrm{H}$, Gwinn JL. Primary Lesions of bone in $1^{\text {st }}$ decade of life: Retrospective survey of biopsy result. Radiology. 1986;160:491-5
17. Bahebeck J, Atangana R, Eyenga V, Pisoh A, Sando Z, Hoffmeyer P. Bone tumors in Cameroon: Incidence, demography and histopathology. Int Orthop 2003;27:3157

18. Xu DL, Zhang XT, Wang GH, Li FB, Hu JY. Clinical features of pathologically confirmed metastatic bone tumors: a report of 390 cases. Ai Zheng. 2005;11:1404-7 